\title{
Algortihm C4.5 in mapping the admission patterns of new Students in Engingeering Computer
}

\author{
Yunita Sari Siregar ${ }^{1)}$, Boni Oktaviana Sembiring ${ }^{2)}$, Hasdiana ${ }^{3)}$, Arie Rafika Dewi ${ }^{4)}$, \\ Herlina Harahap ${ }^{5}$ \\ 1)23)4)5) Universitas Harapan Medan, Indonesia \\ ${ }^{1)}$ yunitasarisiregar1990@gmail.com, ${ }^{2)}$ bonioktaviana @yahoo.co.id, ${ }^{3)}$ hasdiana.stth@gmail.com, \\ 4) arie.juny@gmail.com, ${ }^{5}$ Herlina_Hrp@yahoo.com
}

Submitted : Sep 26, 2021 | Accepted : Oct 10, 2021 | Published : Oct 10, 2021

\begin{abstract}
University of Harapan Medan is one of the private universities in North Sumatra which has computer-based study programs such as Informatics Engineering and Information Systems. Every year this college receives many registrations from students who have completed their education at the school stage. The large number of incoming student data makes it difficult for the admin to select new students who will register. In this study using the $\mathrm{C} 4.5$ algorithm data mining method to map the pattern of student admissions selection in the field of Engineering and computers. The attributes used are the average value of report cards (high, enough, low), basic academic ability tests (very high, high, medium, low, very low), basic computer knowledge tests (very high, high, enough, low, very low) and interviews (good, bad). Data mining is a mathematical calculation process that uses algorithms and requires large data. While the $\mathrm{C} 4.5$ algorithm is an algorithm that processes data by calculating entrophy and information gain, where after the calculation process is carried out, those who get the largest information gain value will become nodes and branches. This $\mathrm{C} 4.5$ algorithm will describe a decision tree that will form a pattern in student selection. The results of this study indicate that in mapping the selection pattern of interview attributes into level 1 nodes, the attributes of the basic computer knowledge test become the level 1 branch, the attributes of the basic academic ability test become the level 2 branch and the attribute average value of report cards becomes the level 3 branch.
\end{abstract}

Keywords: University of Harapan Medan, Engineering and Computers, Students, Data Mining, Algorithm C4.5

\section{INTRODUCTION}

Harapan University Medan is one of the private universities in North Sumatra which has computer-based study programs such as Informatics Engineering and Information Systems. Every year, many students register to continue their education to the tertiary level. The students who registered came from High School (SMA), Vocational High School (SMK), and Madrasah Aliyah (MA). The large number of incoming student data makes it difficult for the admin to do the selection of new student admissions. One of the methods used in mapping student selection patterns is data mining algorithm $\mathrm{C} 4.5$. The $\mathrm{c} 4.5$ algorithm is an algorithm that performs data processing by calculating entropy and information gain. Where after the process of calculating the information gain value, the values obtained for each attribute will be compared. And the ones that get the greatest value will (Handayani, 2019) Data mining is a series of processes to explore the added value of a set of data in the form of knowledge that has not been known manually. Data mining actually has long roots in fields of science such as artificial intelligence, machine learning, statistics and databases. Some of the techniques that are often mentioned in the Data Mining literature include clustering, classification, association rule mining, neural network, and genetic algorithms (Handoko, 2016).

*Corresponding author 
The C4.5 algorithm is one of the algorithms contained in data mining classification and is a model or function that explains or distinguishes concepts or data classes with the aim of estimating the unknown class of an object. In general, the $\mathrm{C} 4.5$ algorithm to build a decision tree is to choose an attribute as the root, create a branch for each value, divide the cases into branches, then repeat the process for each branch until all cases in the branch have the same class (Handayani, 2019)

Previous research conducted by (Lukhayu Pritalia, 2018), concluded that data mining with the C4.5 algorithm can be implemented to determine the availability of e-commerce goods with two categories, namely the goods are not in a condition or not yet available for ordering goods for customers/backorders and goods are in available condition for ordering goods for customers and the results of the analysis using the C4.5 algorithm to determine the time of determining the availability of goods have an accuracy rate of $98.9 \%$.

Based on the above background, the problem in this study is to map the selection pattern of new student admissions in the field of Engineering and Computers using the C4.5 algorithm. And the purpose of this research is to get a pattern mapping in the form of a decision tree, making it easier for admins to select new student admissions in accordance with the fields of engineering and computers.

\section{LITERATURE REVIEW}

Knowledge Discovery In Database (KDD) is a method to obtain knowledge from existing databases. In the database there are tables that are interconnected / related. The results of the knowledge obtained in the process can be used as a knowledge base for decision-making purposes (Yuli Mardi, 2019). Knowledge Discovery In Database (KDD) is an activity that includes collecting, using historical data to find regularities, patterns or relationships in large data and relationships with integration techniques and scientific discoveries, interpretation and visualization of patterns in a number of data sets (Elisa, 2017). Knowledge discovery as a process consists of data cleaning, data integration, data selection, data transformation, data mining, pattern evaluation and knowledge presentation). Data mining refers to the process of mining knowledge from a very large set of data (Firdaus, 2017).

Data mining is defined as the process of finding patterns in data. This process is automated or often semiautomatic. The pattern found must be meaningful and the pattern provides benefits, usually economic benefits. Large amount of data required (Siregar \& Harliana, 2018b). Data mining is an iterative and interactive process to find new patterns or models that are perfect, useful and understandable in a massive database. Data mining contains a search for trends or patterns desired in a large database to help decision makers in the future, these patterns are recognized by certain devices that can provide a useful and insightful analysis of data that can then be studied more thoroughly, which may use other decision support tools (Sikumbang, 2018).

Data mining is between the branches of computer science and statistics, utilizing advances from both disciplines to extract information from large databases. Data mining is a series of processes to explore the added value of knowledge that has not been known from a data set. Data mining is a process that uses statistical, mathematical, artificial intelligence, and machine learning techniques to identify useful information and related knowledge from large databases (Lukhayu Pritalia, 2018).

The characteristics of data mining are as follows (Siregar \& Harliana, 2018a):

a. Data mining deals with the discovery of something hidden and certain data patterns that were not previously known.

b. Data mining usually uses very large data. Usually big data is used to make the results more reliable.

c. Data mining is useful for making critical decisions, especially in strategy.

Data mining techniques are divided into several techniques. Some of the techniques and properties of data mining are as follows (Merdekawati, 2018) :

a. Classification Determines a new data record of one of several pre-defined categories (or classes).

b. Regression predicts the value of a given continuous variable based on the value of another variable, assuming a linear or non-linear dependency model. This technique is widely studied in statistics, the field of artificial neural networks.

c. Clustering partitions data sets into sub-sets or groups in such a way that elements of a particular group have a set of shared properties, with a high degree of similirity in one group and a low level of similirity between groups. Also called unsupervised learning.

d. Association Rules detect a set of attributes that appear together (co-occur) in frequent frequencies and form a number of rules of those sets.

e. Sequential (Sequence Mining) Looking for a number of events that generally occur together

Classification is the process of finding a set of models/functions that describe and distinguish data into specific classes, with the aim of using that model in determining the class of an object of unknown class (Handayani, 2019). The purpose of classification is to find a model of a training set that distinguishes attributes into corresponding categories or classes, the model is then used to classify attributes whose classes have not been previously known (Azwanti, 2018).

*Corresponding author 
Data mining classification is the placement of objects into one of several predefined categories. Classification is widely used to predict classes on a certain label, namely by classifying data (building models) based on training sets and values (class labels) in classifying certain attributes and using them in classifying new data (Susanto \& Sudiyatno, 2014). There are two classification processes consisting of: the learning/training process is to build a model using training data, where each record in the training data is analyzed based on its attribute values using the C4.5 algorithm to obtain the model. Then the testing process is to test the testing data using the model that has been obtained from the training process (Handayani, 2019).

Decision tree is the most popular classification method used. Apart from being relatively fast in construction, the results of the built model are easy to understand. The decision tree works by forming a decision tree that can be concluded with certain classification rules, one of which is C4.5(Azwanti, 2018). Decision trees have several advantages, namely easy to develop a model, easy to understand by users, and able to handle noisy data and unknown data Decision tree consists of several parts, namely inside nodes, branches, and leaf nodes(Pratama \& Hanum, 2016).

The $\mathrm{C} 4.5$ algorithm is one method for making a decision tree based on the training data that has been provided. Some of the developments carried out on the $\mathrm{C} 45$ are, among others, being able to overcome missing values, being able to handle continuous data, and pruning. The C4.5 algorithm was introduced by J. Ross Quinlan which is the development of the ID3 algorithm, the algorithm is used to form a decision tree. Decision tree is considered as one of the most popular approaches, in the decision tree classification consists of a node that forms a root, the root node has no input (Elisa \& Harman, 2019). C4.5 is part of the algorithm for classification in machine learning and data mining. C4.5 is an algorithm that is suitable for classification problems in machine learning and data mining (Fitriana, Ripanti, \& Tursina, 2018)

There are several stages in making a decision tree with the C4.5 algorithm, namely (Merdekawati, 2018):

a. Prepare training data. Training data is usually taken from historical data that has happened before and has been grouped into certain classes.

b. Determine the root of the tree. The root will be taken from the selected attribute, by calculating the gain value of each attribute, the highest gain value will be the first root. Before calculating the gain value from the attribute, first calculate the entropy value. To calculate the entropy value used the formula :

$$
\text { Entropy }(S)=\sum_{i=1}^{n}-p i * \log _{2} p i
$$

Information :

$\mathrm{S}=$ Case Set

$\mathrm{n}=$ number of partitions $\mathrm{S}$

$\mathrm{Pi}=$ Proportion of $\mathrm{Si}$ to $\mathrm{S}$

c. Then calculate the gain value using the formula:

$$
\operatorname{Gain}(S, A)=\operatorname{Entropy}(S)-\sum_{i=1}^{n} \frac{|S i|}{|S|} * \operatorname{Entropy}\left(S_{i}\right)
$$

Information :

$\mathrm{S}=$ Case Set

$\mathrm{A}=$ Features

$\mathrm{n}=$ Number of attribute partitions A

$|\mathrm{Si}|=$ Proportion of $\mathrm{Si}$ to $\mathrm{S}$

$|\mathrm{S}|=$ Number of cases in $\mathrm{S}$

d. Repeat step 2 until all records are partitioned.

e. The decision tree partitioning process will stop when:

1) All records in node $\mathrm{N}$ have the same class.

2) There are no attributes in the partitioned record anymore.

3) There are no records in the empty branch.

\section{METHOD}

At this stage will be explained about the methodology in determining the pattern of selection of new students using the data mining algorithm $\mathrm{c} 4.5$ as follows:

a. Analysis and Identification of Problems. This stage is a step to identify the problem to be discussed, namely the use of data mining algorithm C4.5 in mapping the selection pattern of new students in the computer field.

b. Studying Literature. At this stage regarding theoretical studies that support research 
c. Data collection. In this study, the data that will be used are 70 prospective new students who register at Harapan University. Where the attributes used are: the average value of report cards, basic academic ability tests, basic computer knowledge tests and interviews.

d. Analysis and testing methods In the data analysis stage, it will be done by solving the data mining algorithm C4.5. The resolution steps include:

1) Perform entropy and gain calculations then select attributes as roots

2) Perform entrophy and gain calculations and create branches for each value

3) Split cases in branches

4) Repeat the process in each branch, until all cases in the branch have the same class.

\section{RESULT}

The attribute variables in the implementation of data mining algorithm $\mathrm{C} 4.5$ in mapping the selection pattern of new students in the field of Engineering and computers can be seen in table 1.

Table 1. Attribute Variables

\begin{tabular}{|c|c|}
\hline Name & Atribute \\
\hline A1 & Average Report (Rapor) \\
\hline A2 & Basic Academic Ability Test (TKDA) \\
\hline A3 & Basic Computer Knowledge Test (TPDK) \\
\hline A4 & Interview \\
\hline
\end{tabular}

The process of pattern mapping in the selection of new students in the field of Engineering and computers uses 70 prospective student data. Can be seen in table 2 .

Table 2. Prospective Student Data

\begin{tabular}{|c|c|c|c|c|c|}
\hline \multirow{2}{*}{ Students } & \multicolumn{4}{|c|}{ Atribute } & \\
\cline { 2 - 6 } & A1 & A2 & A3 & A4 & Decision \\
\hline 1 & High & Very High & Enough & Good & Accepted \\
\hline 2 & High & High & Very High & Good & Accepted \\
\hline 3 & Enough & Very High & Enough & Bad & Accepted \\
\hline 4 & Low & High & Low & Bad & Rejected \\
\hline 5 & High & Very High & Very High & Good & Accepted \\
\hline 6 & Enough & Very High & Very Low & Bad & Rejected \\
\hline 7 & High & High & Very Low & Bad & Rejected \\
\hline 8 & Low & Very High & Very Low & Good & Accepted \\
\hline 9 & Low & Medium & High & Bad & Rejected \\
\hline 10 & Enough & High & High & Bad & Accepted \\
\hline
\end{tabular}

To get which attribute will be node 1 , it is necessary to calculate the total entropy. The amount of data used as the research sample amounted to 70, of which 50 prospective students had accepted results, and 20 prospective customers were rejected. To calculate the total entropy value and the entropy value for each attribute with equation 1. after getting the entropy value for each attribute, you can calculate the gain value for each attribute with equation 2 so that the results are in table 3 below.

Table 3. Calculation of Node 1

\begin{tabular}{|c|c|l|c|c|c|c|c|}
\hline Node 1 & Atribute & Class & $\begin{array}{c}\text { Number of } \\
\text { Cases (S) }\end{array}$ & Accepted & Rejected & Entrophy & Gain \\
\cline { 2 - 8 } & Total & & 70 & 50 & 20 & 0.8631206 & \\
\cline { 2 - 8 } & Evaluation & & & & & & 0.010738 \\
\cline { 2 - 8 } & \multirow{2}{*}{$\begin{array}{c}\text { Average } \\
\text { Report }\end{array}$} & High & 21 & 16 & 5 & 0.7918584 & \\
\cline { 2 - 8 } & Enough & 24 & 18 & 6 & 0.8112781 & \\
\cline { 2 - 8 } & Low & 25 & 16 & 9 & 0.9426832 & \\
\hline
\end{tabular}

*Corresponding author 


\begin{tabular}{|c|c|c|c|c|c|c|}
\hline Evaluation & & & & & & 0.0772306 \\
\hline \multirow{5}{*}{$\begin{array}{c}\text { Basic } \\
\text { Academic } \\
\text { Ability Test }\end{array}$} & Very high & 16 & 14 & 2 & 0.5435644 & \\
\hline & High & 16 & 13 & 3 & 0.6962123 & \\
\hline & Medium & 12 & 9 & 3 & 0.8112781 & \\
\hline & Low & 13 & 6 & 7 & 0.9957275 & \\
\hline & Very low & 13 & 8 & 5 & 0.9612366 & \\
\hline Evaluation & & & & & & 0.3319133 \\
\hline \multirow{5}{*}{$\begin{array}{c}\text { Basic } \\
\text { Computer } \\
\text { Knowledge } \\
\text { Test }\end{array}$} & Very high & 14 & 14 & 0 & 0 & \\
\hline & Tall & 15 & 14 & 1 & 0.3533593 & \\
\hline & Enough & 16 & 13 & 3 & 0.6962123 & \\
\hline & Low & 13 & 7 & 6 & 0.9957275 & \\
\hline & Very low & 12 & 2 & 10 & 0.6500224 & \\
\hline Evaluation & & & & & & 1.0116341 \\
\hline \multirow[t]{2}{*}{ Interview } & Good & 22 & 5 & 27 & 0.1231913 & \\
\hline & Bad & 28 & 15 & 43 & 0.4680771 & \\
\hline
\end{tabular}

From table 3 , it can be seen the entropy value and information gain value for each attribute. To get the decision tree node 1, can use the highest gain value. In the decision tree search, the largest gain value is in the interview attribute, which is 1.0116341 . Thus the interview can be used as node 1 . There are 2 classifications on the interview attributes, namely good and bad. Where a good classification becomes a level 1.1 branch and a bad classification becomes a level 1.2 branch.

The next stage is to calculate the value of entrophy and information gain at branch level 1.1. The calculation results can be seen in table 4 .

Table 4. Calculation of Branch Level 1.1

\begin{tabular}{|c|c|c|c|c|c|c|c|}
\hline Node & Atribute & Class & $\begin{array}{l}\text { Number of } \\
\text { Cases (S) }\end{array}$ & Accepted & Rejected & Entrophy & Gain \\
\hline \multirow[t]{17}{*}{1.1} & Interview & Good & 27 & 22 & 5 & 0.691289869 & \\
\hline & Evaluation & & & & & & 0.4539588 \\
\hline & \multirow{3}{*}{$\begin{array}{l}\text { Average } \\
\text { Report }\end{array}$} & High & 10 & 7 & 3 & 0.881290899 & \\
\hline & & Enough & 12 & 10 & 2 & 0.650022422 & \\
\hline & & Low & 5 & 5 & 0 & 0 & \\
\hline & Evaluation & & & & & & 0.5268645 \\
\hline & \multirow{5}{*}{$\begin{array}{c}\text { Basic } \\
\text { Academic } \\
\text { Ability Test }\end{array}$} & Very High & 8 & 8 & 0 & 0 & \\
\hline & & High & 1 & 1 & 0 & 0 & \\
\hline & & Medium & 6 & 6 & 0 & 0 & \\
\hline & & Low & 6 & 3 & 3 & 1 & \\
\hline & & Very low & 6 & 4 & 2 & 0.918295834 & \\
\hline & Evaluation & & & & & & 0.5825807 \\
\hline & \multirow{5}{*}{$\begin{array}{c}\text { Basic } \\
\text { Computer } \\
\text { Knowledge } \\
\text { Test }\end{array}$} & Very High & 7 & 7 & 0 & 0 & \\
\hline & & High & 4 & 4 & 0 & 0 & \\
\hline & & Enough & 8 & 8 & 0 & 0 & \\
\hline & & Low & 3 & 1 & 2 & 0.918295834 & \\
\hline & & Very low & 5 & 2 & 3 & 0.970950594 & \\
\hline
\end{tabular}

From the results in table 4 it can be seen that the attribute with the highest gain is a basic computer knowledge test of 0.5825807. . Thus, the attributes of the basic computer knowledge test can be used as a level $1.1 \mathrm{branch}$. There are 2 classifications on the attributes of the basic computer knowledge test, namely low and very low. Where the low classification becomes a level 2.1 branch and the poor classification becomes a level 2.2 branch.

The next stage is to calculate the value of entrophy and information gain at branch level 1.2. The calculation results can be seen in table 5 .

Table 5. Branch Calculation Level 1.2

*Corresponding author 


\begin{tabular}{|c|c|c|c|c|c|c|c|}
\hline Node & Atribute & Class & $\begin{array}{c}\text { Number of } \\
\text { Cases (S) }\end{array}$ & Accepted & Rejected & Entrophy & Gain \\
\hline \multirow[t]{17}{*}{1.2} & Interview & $\mathrm{Bad}$ & 43 & 28 & 15 & 0.933025295 & \\
\hline & Evaluation & & & & & & 0.0400146 \\
\hline & \multirow{3}{*}{$\begin{array}{c}\text { Average } \\
\text { Report }\end{array}$} & High & 11 & 9 & 2 & 0.684038436 & \\
\hline & & Enough & 12 & 8 & 4 & 0.918295834 & \\
\hline & & Low & 20 & 11 & 9 & 0.992774454 & \\
\hline & Evaluation & & & & & & 0.0165268 \\
\hline & \multirow{5}{*}{$\begin{array}{c}\text { Basic } \\
\text { Academic } \\
\text { Ability Test }\end{array}$} & VeryHigh & 8 & 6 & 2 & 0.811278124 & \\
\hline & & High & 14 & 8 & 3 & 0.937572617 & \\
\hline & & Medium & 6 & 3 & 3 & 1 & \\
\hline & & Low & 7 & 3 & 4 & 0.985228136 & \\
\hline & & Very Low & 7 & 4 & 3 & 0.985228136 & \\
\hline & Evaluation & & & & & & 0.4172243 \\
\hline & \multirow{5}{*}{$\begin{array}{c}\text { Basic } \\
\text { Computer } \\
\text { Knowledge } \\
\text { Test }\end{array}$} & Very High & 7 & 7 & 0 & 0 & \\
\hline & & High & 11 & 10 & 1 & 0.439496987 & \\
\hline & & Enough & 8 & 5 & 3 & 0.954434003 & \\
\hline & & Low & 10 & 6 & 4 & 0.970950594 & \\
\hline & & VeryLow & 7 & 0 & 7 & 0 & \\
\hline
\end{tabular}

From the results in table 5 , it can be seen that the attribute with the highest gain is a basic computer knowledge test of 0.4172243 . Thus the attributes of the basic computer knowledge test can be used as a level 1.2 branch. There are 3 classifications on the attributes of the basic computer knowledge test, namely high,enough and low. Where the high classification becomes a level 2.3 branch, the classification simply becomes a level 2.4 branch and the low classification becomes a level 2.5 branch.

The next stage is to calculate the value of entrophy and information gain at branch level 2.1. The calculation results can be seen in table 6 .

Table 6. Calculation of Branch Level 1.2

\begin{tabular}{|c|c|c|c|c|c|c|c|}
\hline Node & Atribute & Class & $\begin{array}{l}\text { Number of } \\
\text { Cases (S) }\end{array}$ & Accepted & Rejected & Entrophy & Gain \\
\hline \multirow[t]{8}{*}{2.1} & TPDK & Low & 3 & 1 & 2 & 0.918295834 & \\
\hline & Evaluation & & & & & & 0.2516292 \\
\hline & \multirow{2}{*}{$\begin{array}{c}\text { Average } \\
\text { Report }\end{array}$} & High & 2 & 1 & 1 & 1 & \\
\hline & & Enough & 1 & 0 & 1 & 0 & \\
\hline & Evaluation & & & & & & 0.9182958 \\
\hline & \multirow{3}{*}{$\begin{array}{c}\text { Basic } \\
\text { Academic } \\
\text { Ability Test }\end{array}$} & Medium & 1 & 1 & 0 & 0 & \\
\hline & & Low & 1 & 0 & 1 & 0 & \\
\hline & & Very Low & 1 & 0 & 1 & 0 & \\
\hline
\end{tabular}

From the results of table 6 it can be seen that the attribute with the highest gain is the basic academic ability test of 0.9182958 . Thus the attributes of the basic academic ability test can be used as a level 2.1 branch. There are 3 classifications on the attributes of the basic academic ability test, namely medium, low and very low. In the attribute of the basic academic ability test, each classification gets an entrophy value of 0 .

The next stage is to calculate the value of entrophy and information gain at branch level 2.2. The calculation results can be seen in table 7 .

Table 7. Calculation of Branch Level 2.2

\begin{tabular}{|c|c|c|c|c|c|c|c|}
\hline \multirow{2}{*}{ Node } & Atribute & Class & $\begin{array}{c}\text { Number of } \\
\text { Cases (S) }\end{array}$ & Accepted & Rejected & Entrophy & Gain \\
\hline 2.2 & TPDK & Very low & 5 & 2 & 3 & 0.970950594 & \\
\cline { 2 - 8 } & Evaluation & & & & & & 0.5709506 \\
\cline { 2 - 8 } & & High & 2 & 0 & 2 & 0 & \\
\hline
\end{tabular}

*Corresponding author 


\begin{tabular}{|c|c|c|c|c|c|c|}
\hline \multirow{2}{*}{$\begin{array}{c}\text { Average } \\
\text { Report }\end{array}$} & Enough & 2 & 1 & 1 & 1 & \\
\hline & Low & 1 & 1 & 0 & 0 & \\
\hline Evaluation & & & & & & 0.9709506 \\
\hline \multirow{4}{*}{$\begin{array}{c}\text { Basic } \\
\text { Academic } \\
\text { Ability Test }\end{array}$} & Very High & 1 & 1 & 0 & 0 & \\
\hline & Medium & 1 & 1 & 0 & 0 & \\
\hline & Low & 2 & 0 & 2 & 0 & \\
\hline & Very low & 1 & 0 & 1 & 0 & \\
\hline
\end{tabular}

From the results of table 7 it can be seen that the attribute with the highest gain is the basic academic ability test of 0.9709506 . Thus the attributes of the basic academic ability test can be used as a level 2.2 branch. There are 4 classifications on the attributes of the basic academic ability test, namely very high, medium, low, and very low. In the attribute of the basic academic ability test, each classification gets an entrophy value of 0 .

The next stage is to calculate the value of entrophy and information gain at branch level 2.3. The calculation results can be seen in table 8 .

Table 8. Calculation of Branch Level 2.3

\begin{tabular}{|c|c|c|c|c|c|c|c|}
\hline Node & Atribute & Class & $\begin{array}{l}\text { Number of } \\
\text { Cases (S) }\end{array}$ & Accepted & Rejected & Entrophy & Gain \\
\hline \multirow[t]{11}{*}{2.3} & TPDK & High & 11 & 10 & 1 & 0.439496987 & \\
\hline & Evaluation & & & & & & 0.1113479 \\
\hline & \multirow{3}{*}{$\begin{array}{c}\text { Average } \\
\text { Report }\end{array}$} & High & 4 & 4 & 0 & 0 & \\
\hline & & Enough & 2 & 2 & 0 & 0 & \\
\hline & & Low & 5 & 4 & 1 & 0.721928095 & \\
\hline & Evaluation & & & & & & 0.1890527 \\
\hline & \multirow{5}{*}{$\begin{array}{c}\text { Basic } \\
\text { Academic } \\
\text { Ability Test }\end{array}$} & Very High & 1 & 1 & 0 & 0 & \\
\hline & & High & 4 & 4 & 0 & 0 & \\
\hline & & Medium & 3 & 2 & 1 & 0.918295834 & \\
\hline & & Low & 1 & 1 & 0 & 0 & \\
\hline & & Very Low & 2 & 2 & 0 & 0 & \\
\hline
\end{tabular}

From the results in table 8 it can be seen that the attribute with the highest gain is the basic academic ability test of 0.1890527 . Thus the attributes of the basic academic ability test can be used as a level 2.3 branch. There are 5 classifications on the attributes of the basic academic ability test, namely very high, high, medium, low and very low. Where the classification is being branch level 3.1

The next stage is to calculate the value of entrophy and information gain at branch level 2.4. The calculation results can be seen in table 9

Table 9. Calculation of Branch Level 2.4

\begin{tabular}{|c|c|c|c|c|c|c|c|}
\hline Node & Atribute & Class & $\begin{array}{l}\text { Number of } \\
\text { Cases (S) }\end{array}$ & Accepted & Rejected & Entrophy & Gain \\
\hline \multirow[t]{10}{*}{2.4} & TPDK & Enough & 8 & 5 & 3 & 0.954434003 & \\
\hline & Evaluation & & & & & & 0.0157121 \\
\hline & \multirow{3}{*}{$\begin{array}{c}\text { Average } \\
\text { Report }\end{array}$} & High & 2 & 1 & 1 & 1 & \\
\hline & & Enough & 3 & 2 & 1 & 0.918295834 & \\
\hline & & Low & 3 & 2 & 1 & 0.918295834 & \\
\hline & Evaluation & & & & & & 0.954434 \\
\hline & \multirow{4}{*}{$\begin{array}{c}\text { Basic } \\
\text { Academic } \\
\text { Ability Test }\end{array}$} & Very High & 2 & 2 & 0 & 0 & \\
\hline & & High & 3 & 3 & 0 & 0 & \\
\hline & & Low & 2 & 0 & 2 & 0 & \\
\hline & & Very Low & 1 & 0 & 1 & 0 & \\
\hline
\end{tabular}


From the results of table 9 it can be seen that the attribute with the highest gain is the basic academic ability test of 0.954434 . Thus the attributes of the basic academic ability test can be used as a level 2.4 branch. There are 4 classifications on the attributes of the basic academic ability test, namely very high, high, low, and very low. In the attribute of the basic academic ability test, each classification gets an entrophy value of 0 .

The next stage is to calculate the value of entrophy and information gain at branch level 2.5. The calculation results can be seen in table 10 .

Table 10. Calculation of Branch Level 2.5

\begin{tabular}{|c|c|c|c|c|c|c|c|}
\hline Node & Atribute & Class & $\begin{array}{l}\text { Number of } \\
\text { Cases (S) }\end{array}$ & Accepted & Rejected & Entrophy & Gain \\
\hline \multirow[t]{11}{*}{2.5} & TPDK & Low & 10 & 6 & 4 & 0.970950594 & \\
\hline & Evaluation & & & & & & 0.3219281 \\
\hline & \multirow{3}{*}{$\begin{array}{c}\text { Average } \\
\text { Report }\end{array}$} & High & 2 & 2 & 0 & 0 & \\
\hline & & Enough & 4 & 3 & 1 & 0.811278124 & \\
\hline & & Low & 4 & 1 & 3 & 0.811278124 & \\
\hline & Evaluation & & & & & & 0.6464393 \\
\hline & \multirow{5}{*}{$\begin{array}{c}\text { Basic } \\
\text { Academic } \\
\text { Ability Test }\end{array}$} & Very High & 3 & 3 & 0 & 0 & \\
\hline & & High & 4 & 3 & 1 & 0.811278124 & \\
\hline & & Medium & 1 & 0 & 1 & 0 & \\
\hline & & Low & 1 & 0 & 1 & 0 & \\
\hline & & Very Low & 1 & 0 & 1 & 0 & \\
\hline
\end{tabular}

From the results in table 10, it can be seen that the attribute with the highest gain is the basic academic ability test of 0.6464393 . Thus the attributes of the basic academic ability test can be used as a level 2.5 branch. There are 5 classifications on the attributes of the basic academic ability test, namely very high, high, medium, low and very low. Where the high classification becomes a level 3.2 branch.

The next stage is to calculate the value of entrophy and information gain at branch level 3.1. The calculation results can be seen in table 11 .

Table 11. Calculation of Branch Level 3.1

\begin{tabular}{|c|c|c|c|c|c|c|c|}
\hline Node & Atribute & Class & $\begin{array}{c}\text { Number of } \\
\text { Cases (S) }\end{array}$ & Accepted & Rejected & Entrophy & Gain \\
\hline \multirow[t]{5}{*}{3.1} & TKDA & Medium & 3 & 2 & 1 & 0.918295834 & \\
\hline & Evaluation & & & & & & 0.9182958 \\
\hline & \multirow{3}{*}{$\begin{array}{c}\text { Average } \\
\text { Report }\end{array}$} & High & 1 & 1 & 0 & 0 & \\
\hline & & Enough & 1 & 1 & 0 & 0 & \\
\hline & & Low & 1 & 0 & 1 & 0 & \\
\hline
\end{tabular}

From the results in table 11, it can be seen that the average report card attribute is the last level branch with a gain value of 0.9182958 . There are 3 classifications on the average report card attribute, namely high, enaugh, and low.

The next stage is to calculate the value of entrophy and information gain at branch level 3.2. The calculation results can be seen in table 12 ..

Table 12. Calculation of Branch Level 3.2

\begin{tabular}{|c|c|c|c|c|c|c|c|}
\hline Node & Atribute & Class & $\begin{array}{c}\text { Number of } \\
\text { Cases (S) }\end{array}$ & Accepted & Rejected & Entrophy & Gain \\
\hline \multirow[t]{5}{*}{3.2} & TKDA & Low & 4 & 3 & 1 & 0.811278124 & \\
\hline & Evaluation & & & & & & 0.8112781 \\
\hline & \multirow{3}{*}{$\begin{array}{c}\text { Average } \\
\text { Report }\end{array}$} & High & 1 & 1 & 0 & 0 & \\
\hline & & Enough & 2 & 2 & 0 & 0 & \\
\hline & & Low & 1 & 0 & 1 & 0 & \\
\hline
\end{tabular}


From the results in table 12, it can be seen that the average report card attribute is the last level branch with a gain value of 0.8112781 . There are 3 classifications on the average report card attributes, namely high, enough, and low.

\section{DISCUSSIONS}

Based on the results of calculations that have been carried out using the $\mathrm{C} 4.5$ algorithm data mining method in mapping the selection pattern of new students in the field of Engineering and computers to get an overview of the decision tree. It can be seen in Figure 1.

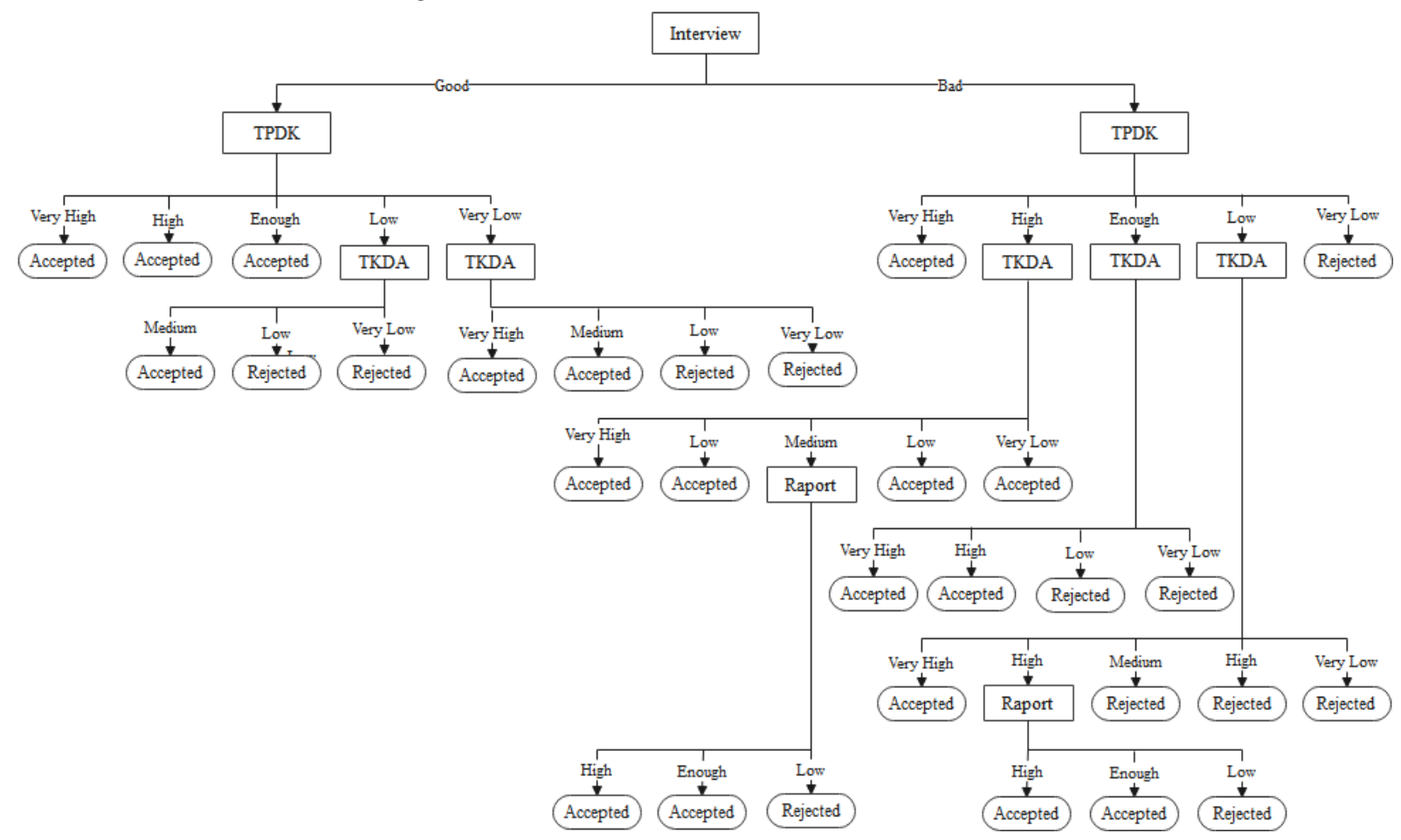

Figure 1. New Student Pattern Mapping Decision Tree

Based on Figure 1, the results of the decision tree calculation in mapping the selection pattern for new student admissions in engineering and computer fields are as follows:

1. If Interview $=$ Good, AND TPDK $=$ Very High THEN Decision $=$ Accepted

2. If Interview $=$ Good, AND TPDK $=$ High THEN Decision $=$ Accepted

3. If Interview $=$ Good, AND TPDK $=$ Enough THEN Decision $=$ Accepted

4. If Interview $=$ Good, $A N D$ TPDK $=$ Low, AND TKDA $=$ Medium THEN Decision $=$ Accepted

5. If Interview $=$ Good, $\mathrm{AND}$ TPDK $=$ Low, $\mathrm{AND}$ TKDA $=$ Low THEN Decision $=$ Rejected

6. If Interview $=$ Good, AND TPDK $=$ Low, AND TKDA $=$ Very Low THEN Decision $=$ Rejected

7. If Interview $=$ Good, AND TPDK $=$ Very Low, AND TKDA $=$ Very High THEN Decision $=$ Accepted

8. If Interview $=$ Good, AND TPDK $=$ Very Low, AND TKDA $=$ Medium THEN Decision $=$ Accepted

9. If Interview $=$ Good, AND TPDK $=$ Very Low, AND TKDA $=$ Low THEN Decision $=$ Rejected

10. If Interview $=$ Good, AND TPDK $=$ Very Low, AND TKDA $=$ Very Low THEN Decision $=$ Rejected

11. If Interview $=$ Bad, AND TPDK $=$ Very High THEN Decision $=$ Accepted

12. If Interview $=$ Bad, AND TPDK $=$ High, AND TKDA $=$ Very High THEN Decision $=$ Accepted

13. If Interview $=$ Bad, AND TPDK $=$ High, AND TKDA $=$ High THEN Decision $=$ Accepted

14. If Interview $=$ Bad, AND TPDK $=$ High, AND TKDA $=$ Medium, AND Raport $=$ High THEN Decision $=$ Accepted

15. If Interview $=$ Bad, AND TPDK $=$ High, AND TKDA $=$ Medium, AND Raport $=$ Enough THEN Decision $=$ Accepted

16. If Interview $=$ Bad, AND TPDK $=$ High, AND TKDA $=$ Medium, AND Raport $=$ Low THEN Decision $=$ Rejected

17. If Interview $=$ Bad, AND TPDK $=$ High, AND TKDA $=$ Low, THEN Decision $=$ Accepted

*Corresponding author 
18. If Interview $=$ Bad, AND TPDK $=$ High, AND TKDA $=$ Very Low, THEN Decision $=$ Accepted 19. If Interview $=$ Bad, AND TPDK $=$ Enough, AND TKDA $=$ Very High, THEN Decision $=$ Accepted 20. If Interview $=$ Bad, AND TPDK $=$ Enough, AND TKDA $=$ High, THEN Decision $=$ Accepted 21. If Interview $=\mathrm{Bad}, \mathrm{AND}$ TPDK $=$ Enough, $\mathrm{AND}$ TKDA $=$ Low, THEN Decision $=$ Rejected 22. If Interview $=$ Bad, AND TPDK $=$ Enough, AND TKDA $=$ Very Low, THEN Decision $=$ Rejected

23. If Interview $=$ Bad, AND TPDK $=$ Low, AND TKDA $=$ High, AND Raport $=$ High THEN Decision $=$ Accepted 24. If Interview $=$ Bad, AND TPDK $=$ Low, AND TKDA $=$ High, AND Raport $=$ Enough THEN Decision $=$ Accepted

25. If Interview $=$ Bad, AND TPDK $=$ Low, AND TKDA $=$ High, AND Raport $=$ Low THEN Decision $=$ Accepted 26. If Interview $=$ Bad, AND TPDK $=$ Low, AND TKDA $=$ High, AND Raport $=$ Enough THEN Decision $=$ Accepted

27. If Interview $=$ Bad, AND TPDK $=$ Low, AND TKDA $=$ Medium, THEN Decision $=$ Rejected

28. If Interview $=$ Bad, AND TPDK $=$ Low, AND TKDA $=$ Low, THEN Decision $=$ Rejected

29. If Interview $=$ Bad, AND TPDK $=$ Low, AND TKDA $=$ Very Low, THEN Decision $=$ Rejected

30. If Interview $=$ Bad, AND TPDK $=$ Very Low, THEN Decision $=$ Rejected

\section{CONCLUSION}

Based on the results of research conducted using data mining methods in determining the nutmeg selection of new student admissions in the field of Engineering and computers, it is concluded that the highest factor affecting 70 new student candidate data is the interview attribute. Then the attribute test of basic computer knowledge becomes the level 1 branch, the attribute of the basic academic ability test becomes the level 2 branch and the attribute of the average value of the report card becomes the last level branch. And in this study resulted in a decision tree of 30 rules

\section{SUGGESTION}

Based on the analysis of data testing in research, as a material for further research development, it can be done by adding a larger amount of data and testing with data mining methods such as the C5.0 algorithm.

\section{REFERENCES}

Azwanti, N. (2018). Analisa Algoritma C4.5 Untuk Memprediksi Penjualan Motor Pada Pt. Capella Dinamik Nusantara Cabang Muka Kuning. Informatika Mulawarman : Jurnal Ilmiah Ilmu Komputer, 13(1), 33-38. https://doi.org/10.30872/jim.v13i1.629

Elisa, E. (2017). Analisa dan Penerapan Algoritma C4.5 Dalam Data Mining Untuk Mengidentifikasi FaktorFaktor Penyebab Kecelakaan Kerja Kontruksi PT.Arupadhatu Adisesanti. Jurnal Online Informatika, 2(1), 36. https://doi.org/10.15575/join.v2i1.71

Elisa, E., \& Harman, R. (2019). ALGORITMA C4.5 UNTUK KLASIFIKASI PEMILIHAN CALON KETUA RW. $7(2), 71-80$.

Firdaus, D. (2017). Penggunaan Data Mining dalam Kegiatan Sistem Pembelajaran Berbantuan Komputer. Jurnal Format, 6(2), 91-97.

Fitriana, J., Ripanti, E. F., \& Tursina, T. (2018). Sistem Pendukung Keputusan Pemilihan Mahasiswa Berprestasi dengan Metode Profile Matching. Jurnal Sistem Dan Teknologi Informasi (JUSTIN), 6(4), 157-164. https://doi.org/10.26418/justin.v6i4.27113

Handayani, I. (2019). Penyakit Disk Hernia Dan Spondylolisthesis Dalam Kolumna Vertebralis. 1(2), 83-88. https://doi.org/10.12928/JASIEK.v13i2.xxxx

Handoko, K. (2016). Penerapan Data Mining Dalam Meningkatkan Mutu Pembelajaran Pada Instansi Perguruan Tinggi Menggunakan Metode K-Means Clustering (Studi Kasus Di Program Studi Tkj Akademi Komunitas Solok Selatan). Jurnal Teknologi Dan Sistem Informasi, 02(03), 31-40. Retrieved from http://teknosi.fti.unand.id/index.php/teknosi/article/view/70

Lukhayu Pritalia, G. (2018). Penerapan Algoritma C4.5 untuk Penentuan Ketersediaan Barang E-commerce. Indonesian Journal of Information Systems, 1(1), 47-56. https://doi.org/10.24002/ijis.v1i1.1727

Merdekawati, A. (2018). Sistem Pendukung Keputusan Penerimaan Beasiswa Menggunakan Algoritma C4.5 (Studi Kasus: Baitul Maal). Jurnal Pendidikan Teknologi Dan Kejuruan, 15(1), 113-123.

*Corresponding author 
https://doi.org/10.23887/jptk-undiksha.v15i1.13067

Pratama, A. Y., \& Hanum, Y. (2016). Penerapan Teknik Data Mining Untuk Menentukan Hasil Seleksi Masuk Sman 99 Jakarta Untuk Siswa/Siswi SMPN 9 Jakarta Menggunakan Decision Tree. 21(1), 49-54. https://doi.org/10.31227/osf.io/vedu7

Sikumbang, E. D. (2018). Penerapan Data Mining Penjualan Sepatu Menggunakan Metode Algoritma Apriori. Jurnal Teknik Komputer AMIK BSI (JTK), Vol 4, No.(September), 1-4.

Siregar, Y. S., \& Harliana, P. (2018a). Algoritma Fuzzy C-Means Pada Aplikasi Matlab Dalam Menentukan Dosen Pembimbing Tugas Akhir. Seminar Nasional Unisla, 213-217.

Siregar, Y. S., \& Harliana, P. (2018b). Analisis perancangan algoritma fuzzy c-means dalam menentukan dosen pembimbing tugas akhir. Jurnal \& Penelitian Teknik Informatika, 3(1), 181-185.

Susanto, H., \& Sudiyatno, S. (2014). Data mining untuk memprediksi prestasi siswa berdasarkan sosial ekonomi, motivasi, kedisiplinan dan prestasi masa lalu. Jurnal Pendidikan Vokasi, 4(2), 222-231. https://doi.org/10.21831/jpv.v4i2.2547

Yuli Mardi. (2019). Data Mining : Klasifikasi Menggunakan Algoritma C4 . 5 Data mining merupakan bagian dari tahapan proses Knowledge Discovery in Database ( KDD ) . Jurnal Edik Informatika. Jurnal Edik Informatika, 2. 